\title{
Prevalence of self-medication in university students: systematic review and meta-analysis
}

Meysam Behzadifar, ${ }^{1}$ Masoud Behzadifar, ${ }^{2}$ Aidin Aryankhesal, ${ }^{3}$ Hamid Ravaghi, ${ }^{3}$ Hamid Reza Baradaran, ${ }^{4}$ Haniye Sadat Sajadi, ${ }^{5}$ Mojtaba Khaksarian ${ }^{6}$ and Nicola Luigi Bragazzi ${ }^{7}$

${ }^{1}$ Social Determinants of Health Research Center, Lorestan University of Medical Sciences, Khorramabad, Islamic Republic of Iran. ${ }^{2}$ Health Management and Economics Research Center, Iran University of Medical Sciences, Tehran, Islamic Republic of Iran. ${ }^{3}$ Department of Health Services Management, School of Health Management and Information Sciences, Iran University of Medical Sciences, Tehran, Islamic Republic of Iran. ${ }^{4}$ Endocrine Research Center, Institute of Endocrinology and Metabolism, Iran University of Medical Sciences, Tehran, Islamic Republic of Iran. ${ }^{5}$ National Institute for Health Research, Tehran University of Medical Sciences, Tehran, Islamic Republic of Iran. ${ }^{6}$ Department of Physiology, School of Medicine, Lorestan University of Medical Sciences, Khorramabad, Islamic Republic of Iran. ${ }^{7}$ School of Public Health, Department of Health Sciences (DISSAL), University of Genoa, Genoa, Italy. (Correspondence to: Masoud Behzadifar: masoudbehzadifar@gmail.com).

\begin{abstract}
Background: Self-medication can lead to serious consequences but its overall prevalence in students is not known.

Aims: The aim of this study was to determine the prevalence of self-medication in students through a systematic review and meta-analysis of studies on the prevalence of self-medication in students across the world.

Methods: PubMed/MEDLINE, EMBASE, ISI/Web of Science and Google Scholar were searched up to October 2017. Studies reporting the prevalence of self-treatment in university students were selected. Data recorded included year of publication, country where the study was conducted, sample size, prevalence of self-medication, sex and mean age of students, and faculty of students (medical or non-medical). A random-effect model was used to determine effect size with a 95\% confidence interval (CI). Heterogeneity across studies was assessed with the $\mathrm{I}^{2}$ test. A sensitivity analysis assessed stability of the findings.

Results: A total of 89 studies were included in the analysis, which comprised 60938 students. The overall prevalence of self-medication in university students was 70.1\% (95\% CI: $64.3-75.4 \%)$. Female students self-medicated more often than male students: odds ratio $=1.45$ (95\% CI\%: 1.17-1.79). The prevalence of self-medication in medical students (97.2\%) was higher than in non-medical students (44.7\%). The $\mathrm{I}^{2}$ test indicated high, statistically significant heterogeneity. The sensitivity analysis showed that the results were stable.

Conclusion: The prevalence of self-medication among students worldwide is high. Programmes on the risks of self-medication and increasing control and monitoring of the sale of drugs are recommended. Facilitating students' access to doctors and health centres could reduce self-medication in students.

Keywords: self-medication, students, prevalence, meta-analysis

Citation: Behzadifar M; Behzadifar M; Aryankhesal A; Ravaghi H; Baradaran HR; Sajadi HS. et al. Prevalence of self-medication in university students: systematic review and meta-analysis. East Mediterr Health J. 2020;26(7):846-857. https://doi.org/10.26719/emhj.20.052

Received: 22/11/17; accepted: 07/11/18

Copyright @ C World Health Organization (WHO) 2020. Open Access. Some rights reserved. This work is available under the CC BY-NC-SA 3.0 IGO license (https://creativecommons.org/licenses/by-nc-sa/3.o/igo)
\end{abstract}

\section{Introduction}

Self-medication is the self-administration of a treatment (either pharmacological or behavioural) without a prescription from a physician or a caregiver (1). Self-medication is an umbrella term, which includes a variety of behaviours, ranging from self-care to disease prevention and disease management. As such, self-medication is not limited to drug intake, but includes also interventions aimed at modifying lifestyle (2). Self-medication is occurring increasingly and is a serious public health concern, both in developing and developed countries (3). Self-medication can lead to serious consequences such as delay in diagnosis of illness, drug resistance, development of co-morbidities and, in some cases, death $(4,5)$.

The number of people reported to self-medicate varies greatly depending on the country in which a study has been conducted and the study design. For instance, in the United States of America (USA) in a period of 6 months, about $71 \%$ of men and $82 \%$ of women had self-medicated at least once (6). In the United Kingdom of Great Britain and Northern Ireland, $41.5 \%$ of people had used drugs without a doctor's prescription (7). In Spain, $27 \%$ of people suffering from pain self-medicated (8). The rise in the prevalence of self-medication is a serious issue for health decision-makers and policy-makers. This increase could be due to higher costs of consulting a doctor, greater availability of drugs and easier access to medications, lack of access to health care facilities and services, and patients' experiences of previous treatments (9).

Determinants of self-medication include the type of physical/psychological illness, the social, cultural and economic status of the patients, and the national laws regulating drug use and sales (10-13). Self-medication may also have its root in the illegal sale of medicines (14).

Young people are among the most vulnerable to selfmedication. In particular, students, because of their higher educational level and ability to find information about 
medications through the Internet, are more likely to selfmedicate $(15,16)$. A precise and reliable estimate of the selfmedication rate is important for health decision-makers and policy-makers so they can design and implement programmes aimed at preventing self-medication. Therefore, we aimed to investigate the prevalence of selfmedication in university students worldwide through a systematic review and meta-analysis of studies published on self-medication in students.

\section{Methods}

We did a two-stage literature search in order to identify the relevant studies. In the first stage, scholarly electronic databases, namely PubMed/MEDLINE via Ovid, EMBASE, ISI/Web of Science and Google Scholar, were searched up to November 2017 using Boolean operators and Medical Subject Headings (MeSH) where appropriate, and restricting the search to articles with full text and/or abstract published in English. The full texts of papers written in languages other than English, were translated by professional translators. The search strategy was as follows: ("prevalence" OR "epidemiology" OR "frequency") AND ("self-medication" OR "self-administration" OR "self-care" OR "illicit use" OR "self-prescription" OR "without doctor's prescription") AND ("university students" OR "medical students" OR "college students" OR "undergraduates").

In the second stage, we also checked the reference lists of the studies retrieved for possible relevant related studies. We included studies that reported the prevalence of self-treatment in students, or those that had the necessary data for calculation of the prevalence. We excluded letters to editor, reviews, case reports or case series, interventional studies, conference proceeding or studies with no available full text. After identification of relevant studies, we examined their titles and abstracts for inclusion based on the above-mentioned inclusion and exclusion criteria. Then, two authors independently reviewed the full text of the articles and extracted the relevant information: surname of first author, year of publication, country where the study was conducted, and then information about the participants including sample size, reported prevalence of self-medication, average age and sex, and type of university where the students studied. If there was disagreement between the reviewers, a third reviewer was consulted as the final referee.

We used the Hoy checklist for evaluation of research quality (risk of bias) for critical appraisal of studies retained in the meta-analysis (17). The checklist includes 10 items, the first four investigate external validity of the studies and the remaining ones relate to internal validity.

To calculate the overall prevalence, we used a random-effect model, computing effect sizes with a 95\% confidence interval of (CI). We examined heterogeneity across studies using the $\mathrm{I}^{2}$ test (18). To investigate the effect of the different variables on heterogeneity, we did a subgroup analysis stratifying participants by income (based on the country in which the study was carried out and retrieved from the World Bank website), region of the study, type of student (medical or non-medical), sample size, study quality and publication year. To assess the stability of the findings, we did a sensitivity analysis examining the effect of removing studies one at a time on the overall outcome (prevalence). To assess publication bias, we used the Egger linear regression test (19). Furthermore, we did a meta-regression analysis to assess the role of year of publication, sample size and mean age of the participants of the included studies: we used these parameters as co-variates, while the dependent variable was the effect size of the studies.

We used Comprehensive Meta-Analysis, version 2.0 (CMA v2.0, Biostat, New Jersey, USA) software for all statistical analyses.

\section{Results}

We report our results according to the Preferred Reporting Items for Systematic Reviews and Meta-analyses (PRISMA) guidelines (20).

We initially retrieved 519 studies: 438 were found through database searching and 81 through additional sources. After removing duplicates, the titles and abstracts of 341 articles were examined. After screening the remaining studies based on the inclusion and exclusion criteria, we excluded 135 articles. We then reviewed the full text of the remaining 206 articles for eligibility, after which we excluded 117 studies with reason (not being relevant to the aim of our systematic review and meta-analysis and/or not providing sufficiently detailed information). We thus retained 89 studies in the final analysis. Figure 1 and Table 1 show the process of study selection and the main characteristics of the studies included, respectively.

The total sample size analysed comprised 60938 students (21-109). Studies were published between 1995 and 2017, the mean age of the students ranged from 17 to 26 years, and sample sizes from 120 to 9161 participants. Thirty-seven $(41.6 \%)$ studies recruited $\leq 400$ participants, while $52(58.4 \%)$ had > 400 participants. As regards region where the studies were done, 54 (60.7\%) studies were done in Asia, 14 (15.7\%) in Africa, 11 (12.4\%) in South America, 7 (7.9\%) in Europe, 2 (2.2\%) in the USA, and 1 (1.1\%) in Australia. Most studies (62, 69.7\%) were done in middle-income countries, $19(21.3 \%)$ in high-income countries and 8 (9.0\%) in low-income countries. Fortysix $(51.7 \%)$ studies explored self-medication in medical students, and 25 in non-medical students; information on students' faculty was not provided in the 18 remaining studies. As regards study quality, 52 (58.4\%) articles were judged of high (score 16-22) quality, 28 (31.5\%) of medium (7-15) quality and 9 (10.1\%) of low (1 to 6) quality.

The overall prevalence of self-medication in university students was $70.1 \%$ (95\% CI: 64.3-75.4), ranging from $7.9 \%$ to $99 \%$, as shown in the forest plot (Figure 2, available online). The $\mathrm{I}^{2}$ test revealed a high, statistically significant heterogeneity of $99.39 \%$. 


\begin{tabular}{|c|c|c|c|c|c|c|}
\hline $\begin{array}{l}\text { First author } \\
\text { (Reference) }\end{array}$ & Year & Country & $\begin{array}{c}\text { Mean age of } \\
\text { students (SD), years }\end{array}$ & $\begin{array}{l}\text { Sample } \\
\text { size }\end{array}$ & $\begin{array}{l}\text { Reported prevalence of } \\
\text { self-medication } \%\end{array}$ & $\begin{array}{c}\text { Study } \\
\text { quality score }\end{array}$ \\
\hline Lau (21) & 1995 & China, Hong Kong SAR & 20.5 (SD 2.2) & 563 & 94.0 & $7-15$ \\
\hline Burak (22) & 2000 & USA & NA & 471 & 89.0 & $16-22$ \\
\hline Cabrita (23) & 2004 & Portugal & NA & 1145 & 7.9 & $16-22$ \\
\hline Aguado (24) & 2005 & Argentina & NA & 216 & 85.0 & $7-15$ \\
\hline McCabe (25) & 2005 & USA & NA & 9161 & NA & $16-22$ \\
\hline James (26) & 2006 & Bahrain & 18.01 (SD 0.78) & 134 & 44.8 & 7-15 \\
\hline Awad (27) & 2007 & Sudan & NA & 1121 & 79.5 & $1-6$ \\
\hline Castronuovo (28) & 2007 & Argentina & NA & 462 & 95.0 & $16-22$ \\
\hline Hussain (29) & 2008 & Pakistan & NA & 200 & 42.0 & $7-15$ \\
\hline Sawalha (30) & 2008 & Palestine & 20 (SD 1.7) & 1581 & 66.1 & $7-15$ \\
\hline Zafar (31) & 2008 & Pakistan & 21 (SD 1.8) & 572 & 76.0 & $1-6$ \\
\hline Sawalha (32) & 2008 & Palestine & 19.9 (SD 1.7) & 1581 & 98.0 & $7-15$ \\
\hline Sarahroodi (33) & 2009 & Iran (IR) & NA & 160 & 53.0 & $1-6$ \\
\hline Abay (34) & 2010 & Ethiopia & NA & 213 & 38.5 & 7-15 \\
\hline de Aquino (35) & 2010 & Brazil & NA & 223 & 65.5 & $16-22$ \\
\hline Marine (36) & 2010 & Argentina & NA & 5170 & 50.1 & $16-22$ \\
\hline Sapkota (37) & 2010 & Nigeria & NA & 706 & 24.0 & 7-15 \\
\hline Sarahroodi (38) & 2010 & Iran (IR) & $21.5(\mathrm{SD} 0.25)$ & 195 & NA & $16-22$ \\
\hline Verma (39) & 2010 & India & 20.13 (SD 2.32) & 1022 & 87.0 & $7-15$ \\
\hline Chowdhury (40) & 2011 & Bangladesh & NA & 1107 & 16.0 & $7-15$ \\
\hline El Ezz (41) & 2011 & Egypt & 19.1 (SD 1.5) & 300 & 55.0 & 7-15 \\
\hline Gutema (42) & 2011 & Ethiopia & 21.5 & 148 & 43.2 & $7-15$ \\
\hline Klemenc-Ketis (43) & 2011 & Slovenia & NA & 410 & 94.9 & $16-22$ \\
\hline Klemenc-Ketis (44) & 2011 & Slovenia & 22.4 (SD 3.24) & 1294 & NA & $16-22$ \\
\hline Mumtaz (45) & 2011 & Pakistan & 22 & 207 & 80.4 & $1-6$ \\
\hline Souza (46) & 2011 & Brazil & 21 (SD 1.95) & 196 & 38.8 & $16-22$ \\
\hline Auta (47) & 2012 & Nigeria & NA & 188 & 53.2 & $1-6$ \\
\hline Banerjee (48) & 2012 & India & 21.03 (SD 4.82) & 468 & 57.1 & 7-15 \\
\hline da Silva (49) & 2012 & Brazil & 22 (SD 6.17) & 789 & 86.4 & $16-22$ \\
\hline da Silva (50) & 2012 & Brazil & 21.5 & 200 & 92.0 & $16-22$ \\
\hline Donkor (51) & 2012 & Ghana & NA & 600 & 70.0 & 7-15 \\
\hline Galato (52) & 2012 & Brazil & 22.9 (SD 4.2) & 342 & 37.0 & $7-15$ \\
\hline Ibrahim (53) & 2012 & United Arab Emirates & 19.5 (SD 2.4) & 169 & 86.0 & $16-22$ \\
\hline Murtaza (54) & 2012 & Pakistan & NA & 450 & 78.7 & $16-22$ \\
\hline Osemene (55) & 2012 & Nigeria & NA & 2000 & NA & $7-15$ \\
\hline $\operatorname{Pan}(56)$ & 2012 & China & NA & 1300 & 47.8 & $16-22$ \\
\hline Suaifan (57) & 2012 & Jordan & NA & 570 & NA & $16-22$ \\
\hline Tabiei (58) & 2012 & Iran (IR) & NA & 1048 & 86.7 & $16-22$ \\
\hline Angamo (59) & 2012 & Ethiopia & $18-24$ & 403 & 45.9 & $16-22$ \\
\hline Betancourt (6o) & 2013 & Puerto Rico & NA & 275 & 27.6 & $1-6$ \\
\hline Imtiaz (61) & 2013 & Pakistan & NA & 300 & 83.0 & 7-15 \\
\hline Kumar (62) & 2013 & India & 20.3 (SD 61.5) & 440 & 78.6 & $16-22$ \\
\hline Purreza (63) & 2013 & Iran (IR) & NA & 600 & 35.7 & $16-22$ \\
\hline Ullah (64) & 2013 & Pakistan & NA & 256 & 95.5 & $16-22$ \\
\hline Al Hussaini (65) & 2014 & Kuwait & NA & 837 & 97.8 & $1-6$ \\
\hline Brlic (66) & 2014 & Croatia & NA & 389 & NA & $16-22$ \\
\hline Damian (67) & 2014 & Romania & NA & 281 & 41.0 & $16-22$ \\
\hline Flaiti (68) & 2014 & Oman & 22.3 & 450 & 36.7 & $16-22$ \\
\hline Ghafouri (69) & 2014 & Iran (IR) & 22.84 (SD 4.19 & 590 & 41.9 & $7-15$ \\
\hline Lukovic (70) & 2014 & Serbia & NA & 1295 & 79.9 & $16-22$ \\
\hline
\end{tabular}




\begin{tabular}{|c|c|c|c|c|c|c|}
\hline $\begin{array}{l}\text { First author } \\
\text { (Reference) }\end{array}$ & Year & Country & $\begin{array}{c}\text { Mean age of } \\
\text { students (SD), years }\end{array}$ & $\begin{array}{l}\text { Sample } \\
\text { size }\end{array}$ & $\begin{array}{l}\text { Reported prevalence of } \\
\text { self-medication \% }\end{array}$ & $\begin{array}{c}\text { Study } \\
\text { quality score }\end{array}$ \\
\hline $\operatorname{Lv}(71)$ & 2014 & China & NA & 731 & 40.2 & $16-22$ \\
\hline Martinez (72) & 2014 & Brazil & 22.09 (SD 9.94) & 498 & NA & $16-22$ \\
\hline Pirzadeh (73) & 2014 & $\operatorname{Iran}(\mathrm{IR})$ & 22.00 (SD 2.77) & 197 & 85.0 & $16-22$ \\
\hline Saeed (74) & 2014 & Saudi Arabia & 21.95 (SD 3.43) & 354 & 86.2 & $16-22$ \\
\hline Shah (75) & 2014 & Pakistan & 20.04 (SD 1.74) & 431 & 47.6 & $7-15$ \\
\hline Sharif (76) & 2014 & United Arab Emirates & 20.4 (SD 2.6) & 200 & 59.0 & $7-15$ \\
\hline Patil (77) & 2014 & India & 20.4 (SD 1.22 & 440 & 88.2 & $16-22$ \\
\hline Alam (78) & 2015 & Bangladesh & NA & 500 & NA & 7-15 \\
\hline Chiribagula (79) & 2015 & $\begin{array}{l}\text { Democratic Republic of } \\
\text { the Congo }\end{array}$ & 23 & 510 & 99.0 & $16-22$ \\
\hline Ghaieth (80) & 2015 & Libya & NA & 363 & NA & 7-15 \\
\hline Gholipour (81) & 2015 & Iran (IR) & NA & 320 & 48.0 & $16-22$ \\
\hline Gunawardhana (82) & 2015 & Sri Lanka & NA & 175 & 85.1 & $1-6$ \\
\hline Ibrahim (83) & 2015 & Saudi Arabia & NA & 504 & NA & $16-22$ \\
\hline Sharma (84) & 2015 & India & NA & 624 & NA & $7-15$ \\
\hline Aashi (85) & 2016 & Saudi Arabia & NA & 507 & 74.0 & $16-22$ \\
\hline Ahamdi (86) & 2016 & $\operatorname{Iran}(\mathrm{IR})$ & 21.63 (SD 1.92) & 364 & 33.7 & $16-22$ \\
\hline Albasheer (87) & 2016 & Saudi Arabia & NA & 300 & 87.0 & $16-22$ \\
\hline $\operatorname{Ali}(88)$ & 2016 & Pakistan & 23.5 (SD 3.6) & 150 & 52.7 & $16-22$ \\
\hline Alkhatatbeh (89) & 2016 & Jordan & NA & 1317 & 78.5 & $16-22$ \\
\hline Banerjee (90) & 2016 & Nepal & NA & 488 & 81.4 & $16-22$ \\
\hline Birru (91) & 2016 & Ethiopia & 21 (SD 1.61) & 464 & 77.6 & $16-22$ \\
\hline Ibrahim (92) & 2016 & Malaysia & 22 (SD 1.7) & 363 & 46.6 & $7-15$ \\
\hline Iuras (93) & 2016 & Brazil & NA & 180 & 89.0 & $1-6$ \\
\hline Jamshed (94) & 2016 & Malaysia & 19.55 (SD 1.761 & 461 & 57.2 & $16-22$ \\
\hline Jimenez-Nunez (95) & 2016 & Spain & NA & 249 & 72.7 & $16-22$ \\
\hline Johnson (96) & 2016 & India & $17-26$ & 736 & NA & $16-22$ \\
\hline Juibari (97) & 2016 & Iran (IR) & 21.01 (SD 1.46) & 175 & 45.7 & $16-22$ \\
\hline Kumar (98) & 2016 & India & NA & 664 & NA & $16-22$ \\
\hline Morowatisharifabad (99) & 2016 & Iran (IR) & 21.9 (SD 2.41) & 237 & 45.1 & $16-22$ \\
\hline Noor (100) & 2016 & Pakistan & 20.64 (SD 1.68) & 413 & 96.9 & $7-15$ \\
\hline Saleem (101) & 2016 & Pakistan & $21.2(\mathrm{SD} 2.2)$ & 380 & NA & $16-22$ \\
\hline Williams (102) & 2016 & Australia & NA & 120 & 91.7 & $16-22$ \\
\hline Yadav (103) & 2016 & Nepal & NA & 570 & 90.1 & $7-15$ \\
\hline Zhu (104) & 2016 & China & 21 & 660 & 47.9 & $16-22$ \\
\hline Al-Ameri (105) & 2017 & Iraq & 19.8 (SD 1.6) & 1435 & 92.4 & $16-22$ \\
\hline Gelayee (106) & 2017 & Ethiopia & 21.26 (SD 1.76) & 385 & 32.7 & $7-15$ \\
\hline Haroun (107) & 2017 & Syrian Arab Republic & NA & 436 & NA & $16-22$ \\
\hline Helal (108) & 2017 & Egypt & 20 (SD 0.7) & 800 & 62.9 & $16-22$ \\
\hline Jakaria (109) & 2017 & Bangladesh & NA & 439 & 52.2 & $7-15$ \\
\hline
\end{tabular}

SD: standard deviation, SAR: Special Administrative, Region, USA: United States of America, NA: not available, IR: Islamic Republic of

Results of the subgroup analysis based on income level, geographical region, sample size, study quality, year of publication, type of students (medical or non-medical) and sex are shown in Table 2. Heterogeneity as assessed by the $\mathrm{I}^{2}$ statistic was high, statistically significant for all these subgroup analyses and ranging from $87.77 \%$ to $99.89 \%$. Stratifying according to the income level of the country in which the study was conducted, the prevalence of self-medication was $65 \%$ (95\% CI: $44.8-$
80.9\%), $71.8 \%$ (95\% CI: $66.8-76.3 \%$ ) and $67.2 \%$ (95\% CI: 46.5-82.9\%) in high-, middle- and low-income countries, respectively. Based on region, the highest prevalence of self-medication was $91.7 \%$ (95\% CI: 85.2-95.5\%) in Oceania and the lowest was 55.8\% (95\% CI: 28-80.4) in Europe. The prevalence of self-medication was higher in female students $(76.6 \%$ (95\% CI: $65.0-85.2 \%))$ than male students (66.9\% (95\% CI: $56.4-75.9 \%)$ ), and in medical students (97.2\% (95\% CI: 95.4-98.3\%)) than non-medical students 


\begin{tabular}{|c|c|c|c|c|c|c|}
\hline Variable & No. studies & No. participants & Prevalence (95\% CI), \% & Q test & $\mathbf{I}^{2}, \%$ & P-value \\
\hline \multicolumn{7}{|l|}{ Income } \\
\hline High & 19 & 17532 & $65.0(44.8-80.9)$ & 4976.93 & 99.63 & $<0.001$ \\
\hline Middle & 62 & 40225 & $71.8(66.8-76.3)$ & 5523.91 & 98.89 & $<0.001$ \\
\hline Low & 8 & 3181 & $67.2(46.5-82.9)$ & 1006.87 & 99.30 & $<0.001$ \\
\hline \multicolumn{7}{|l|}{ Region } \\
\hline Asia & 54 & 29371 & $71.7(66.6-76.4)$ & 4082.90 & 98.70 & $<0.001$ \\
\hline Europe & 7 & 5063 & $55.8(28-80.4)$ & 1485.80 & 99.59 & $<0.001$ \\
\hline Americas & 13 & 18183 & $65(38.8-84.5)$ & 4901.85 & 99.75 & $<0.001$ \\
\hline Africa & 14 & 8201 & $71.6(56.7-83.0)$ & 2050.22 & 99.36 & $<0.001$ \\
\hline Oceania & 1 & 120 & $91.7(85.2-95.5)$ & - & - & - \\
\hline \multicolumn{7}{|l|}{ Sample size } \\
\hline$\leq 400$ & 37 & 9104 & $61.9(55.1-68.3)$ & 2752.36 & 98.69 & $<0.001$ \\
\hline$>400$ & 52 & 51834 & $75.3(66.7-82.2)$ & 11739.21 & 99.56 & $<0.001$ \\
\hline \multicolumn{7}{|l|}{ Quality of study } \\
\hline High (16-22) & 52 & 40864 & $68.7(60.2-76)$ & 10794.22 & 99.52 & $<0.001$ \\
\hline Medium (7-15) & 28 & 16359 & $72.3(63-80)$ & 2780.98 & 99.02 & $<0.001$ \\
\hline Low (1-6) & 9 & 3715 & $71.2(58.7-81.1)$ & 481.24 & 98.33 & $<0.001$ \\
\hline \multicolumn{7}{|l|}{ Year of publication } \\
\hline $1995-2001$ & 2 & 1034 & $91.7(85.4-95.5)$ & 8.18 & 87.77 & $<0.001$ \\
\hline $2002-2006$ & 4 & 10656 & $30.2(8.9-65.6)$ & 582.55 & 99.48 & $<0.001$ \\
\hline $2007-2011$ & 20 & 16868 & $68(56.4-77.7)$ & 2894.05 & 99.33 & $<0.001$ \\
\hline $2012-2017$ & 63 & 32380 & $71.8(66.66-76.4)$ & 5061.25 & 98.77 & $<0.001$ \\
\hline \multicolumn{7}{|l|}{ Type of students ${ }^{a}$} \\
\hline Medical & 46 & 15497 & $97.2(95.4-98.3)$ & 1802.02 & 97.5 & $<0.001$ \\
\hline Non-medical & 25 & 23799 & $44.7(29.7-60.7)$ & 8431.75 & 99.71 & $<0.001$ \\
\hline \multicolumn{7}{|l|}{$S e x^{b}$} \\
\hline Female & 23 & 9392 & $76.6(65.0-85.2)$ & 1956.78 & 98.87 & $<0.001$ \\
\hline Male & 23 & 7021 & $66.9(56.4-75.9)$ & 1177.13 & 98.13 & $<0.001$ \\
\hline
\end{tabular}

${ }^{a}$ The faculty of the students was not given in 18 studies.

${ }^{b}$ The sex of the students was not given in 43 studies.

(44.7\% 95\% CI: 29.7-60.7\%)). Between 2012 and 2017, the later studies included, the prevalence of self-medication was $71.8 \%$ (95\% CI: 66.66-76.4\%).

The effect of moderator variables (i.e. predictors of self-medication) - publication year, sample size of studies and the mean age of participants - was evaluated using meta-regression analyses (Table 3). All these moderator variables were statistically significantly associated with the prevalence of self-medication $(P<0.001)$.

The odds ratio of self-medication in female versus

\begin{tabular}{|c|c|c|c|c|c|}
\hline \multicolumn{6}{|c|}{$\begin{array}{l}\text { Table } 3 \text { Meta-regression analysis of effect of variables on the } \\
\text { prevalence of self-medication }\end{array}$} \\
\hline Moderator & $\begin{array}{l}\text { No. } \\
\text { studies }\end{array}$ & Coefficient & $z$-value & P-value & $\mathbf{I}^{2}$ \\
\hline $\begin{array}{l}\text { Year of } \\
\text { publication }\end{array}$ & 89 & 0.11 & 42.48 & $<0.001$ & 1.46 \\
\hline $\begin{array}{l}\text { Sample size } \\
\text { of studies }\end{array}$ & 89 & -0.00 & -66.12 & $<0.001$ & 1.22 \\
\hline $\begin{array}{l}\text { Mean age of } \\
\text { participants }\end{array}$ & 40 & -0.34 & -19.28 & $<0.001$ & 0.94 \\
\hline
\end{tabular}

male students was 1.45 (95 CI\%: 1.17-1.79), that is to say self-medication was significantly more prevalent in females (Figure 3, available online).

The sensitivity analysis showed the stability of the results (Figure 4, see Supplement 1, available online). We sorted studies according to the year of publication and did a cumulative meta-analysis. The results showed that the prevalence of self-medication did not generally change, confirming once again the robustness of our findings (Figure 5, see Supplement 1, available online). In addition, we sorted studies by sample size and again the prevalence of self-medication did not generally change (Figure 6, see Supplement 1, available online). This confirms the reliability and robustness of our findings.

Finally, we found evidence of publication bias based on the Egger linear regression test. The intercept was 12.57 (95\% CI: 7.24-17.90), $t=4.68$, degrees of freedom $=87, P<0.001)$. Publication bias was confirmed by the visual inspection of the funnel plot, which is shown in Figure 7 (see Supplement 1, available online). 
Figure 1 Flow diagram of selection of studies for inclusion in the systematic review and meta-analysis

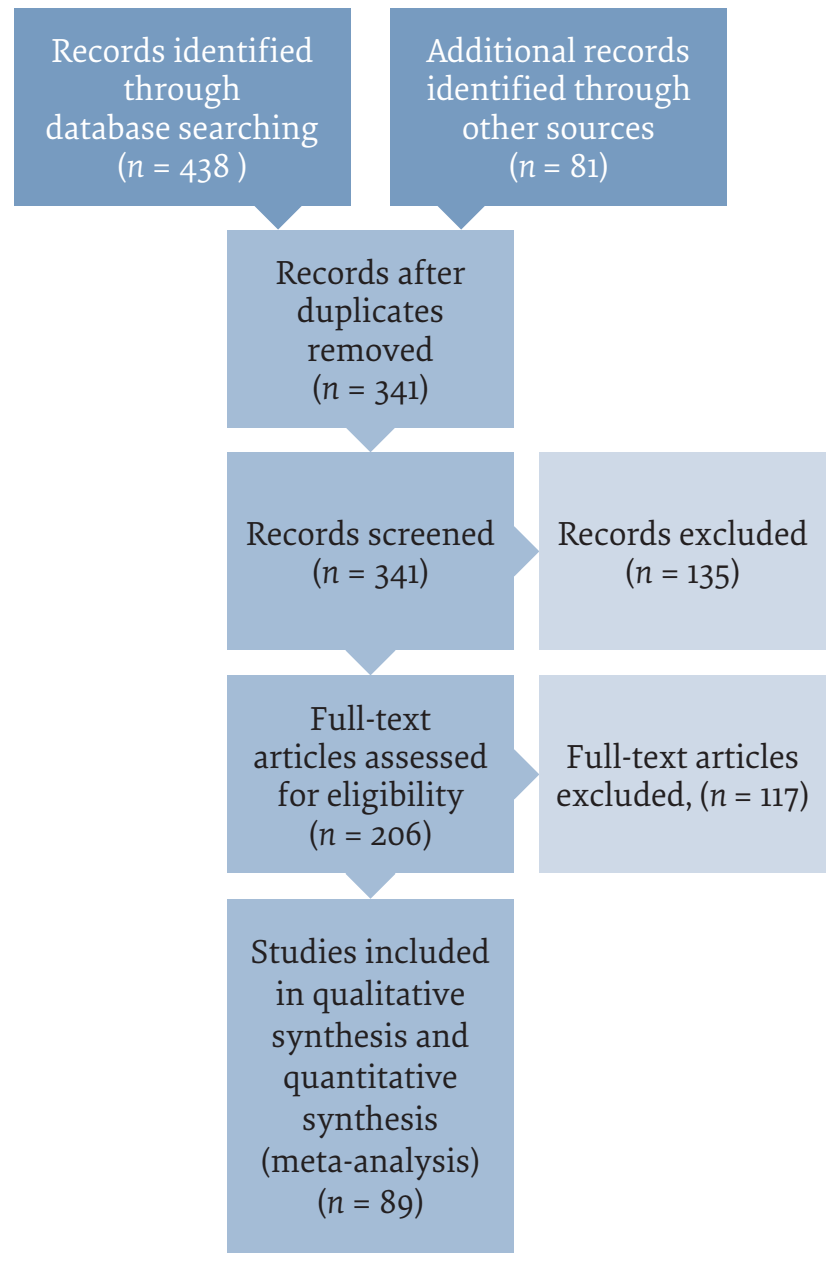

\section{Discussion}

Our results show that the prevalence of self-medication in students worldwide was $70.1 \%$. The range of prevalence of self-medication in students $(7.9-99.0 \%)$ was higher than self-medication in adolescents aged 13-18 years (prevalence rate ranging from $2 \%$ to $92 \%$ ) (110). In addition, the prevalence of self-medication in students was higher than non-student adults (for instance 35.0\% (95\% CI: $29.0-40.0 \%$ ) in Brazil) (111). A possible factor for such a high prevalence of self-medication in students could be the high level of education. Indeed, awareness and knowledge of drugs among students has been reported as a key factor in students' behaviour in seeking health care. Students are much more likely to read books and materials on different medications and their benefits for treating illnesses $(15,16)$. This knowledge may lead to them self-prescribe treatment rather than seeing a physician. Furthermore, in some cases, living on campus may change students attitudes and make them more prone to self-medication (112). We found that the prevalence of self-medication in students in medical sciences $(97.2 \%)$ was more than twice the prevalence of self-medication in non-medical students (47.7\%), which, as hypothesized before, could be because medical students generally have a greater awareness and knowl- edge about drugs (113). Students of medical sciences sometimes try different drugs which they will use in their future profession. In addition, the frequent use of medicines during their training in health centres and their easy access to medications could make them more likely to use medications to treat themselves $(77,96)$.

Our subgroup analyses showed that the prevalence of self-medication was lower in high-income countries than middle- and low-income countries. More up-to-date knowledge on the consequences of self-medication, as well as the health counselling against self-medication by health care professionals and the easier access to health care in high-income countries could explain such difference (114). At the same time, lower socioeconomic status could lead people to self-medicate, because they cannot afford to go to a doctor. Today, most people have easier access to drugs than before, which can be dangerous for health, especially if poor-quality and inadequate medications are used (115).

Moreover, we found that the prevalence of selfmedication was higher in women than men $(\mathrm{OR}=1.45)$. This could be because women may use medications before they get ill (116). Female use more drugs because of menstruation and gynaecological problems, and usually they look for information about their illnesses (117). However, some studies found different results $(118,119)$.

Asian students were more likely to self-medicate compared with students in other regions. Cultural, ethnic, economic and social factors can explain such differences in prevalence. Poor supervisory structures for purchase of medications, easy access to medicine, lack of insurance coverage for some students and misconceptions about taking medications without referring to a doctor can increase the prevalence of self-medication $(11,120)$.

We found a statistically significant time trend in self-medication worldwide. Despite efforts made by countries to reduce self-medication in students, this practice is still rising; therefore new and more effective measures are urgently needed (9). In addition, based on the result of our meta-regression analyses, the mean age of participants was associated with the prevalence of self-medication, with younger students being more likely to self-medicate. This may be due to negative effects of self-medication experienced when students were younger. When someone suffers from complications of self-medication, fear of suffering from other physical or mental problems may prevent him/her from self-medicating again (77).

The strengths of our study include: its large sample size, the subgroup analysis, sensitivity analysis, cumulative meta-analysis and meta-regression analyses. All these analyses indicate the methodological rigor of our systematic review and meta-analysis. On the other hand, our review has some limitations. We observed high, statistically significant heterogeneity across the studies included, which could be due to methodological differences in the different studies. Publication bias 
was also statistically significant so the results should be interpreted/generalized with caution. In addition, the quality of the studies included differed and the inclusion of some poor-quality investigations might have affected the final estimation.

\section{Conclusion}

The results of this study showed that the prevalence of self-medication in students worldwide was high.
We recommend that health decision-makers and policy-makers consider developing and implementing programmes about the risks of self-medication, and increasing control and monitoring of the sale of drugs. Facilitating students' access to doctors and health care centres could be effective in reducing self-medication among students.

Funding: None.

Competing interests: None declared

\section{Prévalence de l'automédication chez les étudiants universitaires : examen systématique et méta-analyse}

\section{Résumé}

Contexte : L'automédication peut avoir de graves conséquences, mais sa prévalence globale chez les étudiants n'est pas connue.

Objectifs : La présente étude avait pour objectif de mesurer la prévalence de l'automédication chez les étudiants au moyen d'un examen systématique et d'une méta-analyse des études portant sur la prévalence de l'automédication chez les étudiants à travers le monde.

Méthodes : Les bases de données PubMed/MEDLINE, EMBASE, ISI/Web of Science et Google Scholar ont été consultées jusqu'au mois d'octobre 2017. Les études portant sur la prévalence de l'automédication chez les étudiants universitaires ont été sélectionnées. Les données enregistrées comprenaient l'année de publication de l'étude, le pays où l'étude avait été menée, la taille de l'échantillon, la prévalence de l'automédication, le sexe et l'âge moyen des étudiants, ainsi que la faculté de ces derniers (discipline médicale ou non). Un modèle à effet aléatoire a été utilisé pour déterminer la taille de l'effet avec un intervalle de confiance (IC) de $95 \%$. L'hétérogénéité des résultats entre les différentes études a été évaluée à l'aide du test $\mathrm{I}^{2}$. Une analyse de sensibilité a permis d'évaluer la stabilité des résultats.

Résultats : Au total, 89 études ont été incluses dans l'analyse, qui comprenait 60938 étudiants. La prévalence globale de l'automédication chez les étudiants universitaires était de 70,1 \% (IC à 95\%: 64,3-75,4 \%). Les étudiantes s'auto-médicamentent plus souvent que les étudiants : odds ratio $=1,45$ (IC à $95 \%: 1,17-1,79 \%$ ). La prévalence de l'automédication chez les étudiants en médecine (97,2\%) était plus élevée que chez les étudiants des filières non médicales (44,7\%). Le test $\mathrm{I}^{2}$ a révélé une hétérogénéité élevée et statistiquement significative. L'analyse de sensibilité a permis de conclure que les résultats étaient stables.

Conclusions : La prévalence de l'automédication chez les étudiants du monde entier est élevée. Il est recommandé de mettre en place des programmes sur les risques liés à l'automédication et renforcer le contrôle et la surveillance de la vente de médicaments. Le fait de faciliter l'accès des étudiants à des médecins et à des centres de santé pourrait permettre de réduire l'automédication chez les étudiants.

$$
\begin{aligned}
& \text { انثشار التداوي الذاتي بين طلاب الجامعات: استعر اض منهجي وتحليل تلوي } \\
& \text { ميثم بهز ادى فر، مسعود بهز ادى فر، آيدين آرين خصال، حيد رواقي، حميد برادران، هانيه سجادي، بجتبى خاكساريان، نيكلا براكازي } \\
& \text { الخالاصة } \\
& \text { الخلفية: يُمكن أن يُسفر التداوي الذاتي عن عواقب وخيمة، ولكن من غير المعلوم المعدل الكلي لانتشاره بين الطلاب. }
\end{aligned}
$$

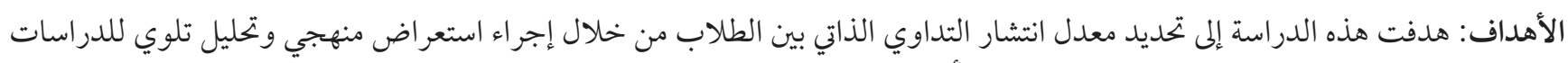

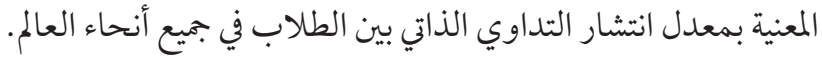

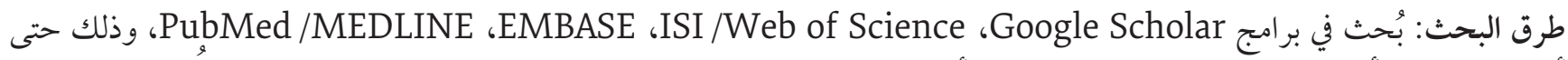

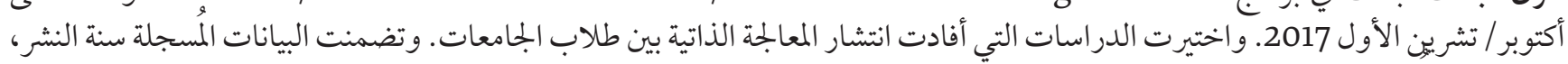

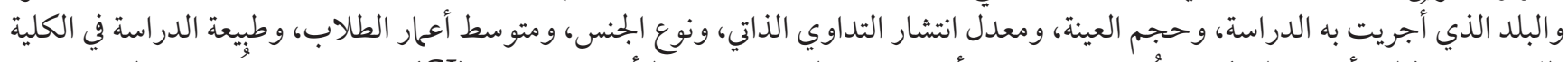

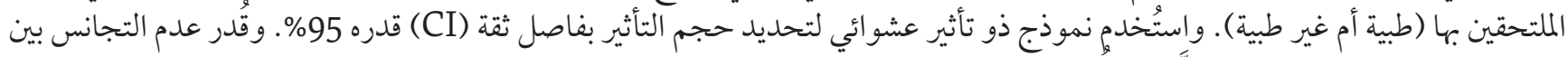

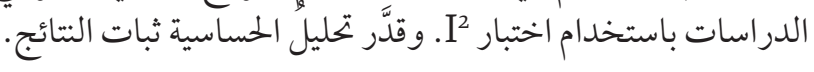

النتائج: بلغ إجمالي الدراسات التي تضمنها التحليل 89 دراسة شملت 638 إسلات 60 طالباً. وبلغ المعدل الكلي لانتشار التداوي الذاتي بين طلاب

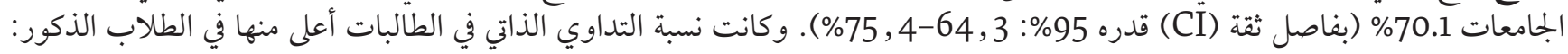




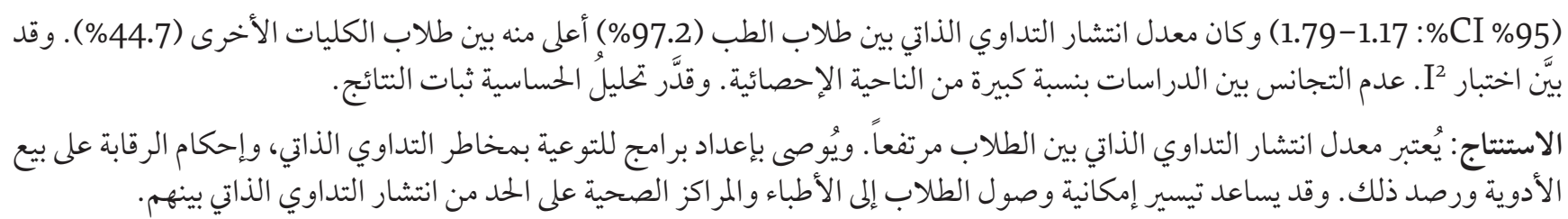

\section{References}

1. Guidelines for the regulatory assessment of medicinal products for use in self-medication. Geneva: World Health Organization; 2000. (http://apps.who.int/medicinedocs/pdf/s2218e/s2218e.pdf, accessed 22 November 2017).

2. Galato D, Galafassi LM, Alano GM, Trauthman SC. Responsible self-medication: review of the process of pharmaceutical attendance. Braz J Pharm Sci. 2009;45(4):626-33. http://doi.org/10.1590/S1984-82502009000400004

3. Ocan M, Obuku EA, Bwanga F, Akena D, Richard S, Ogwal-Okeng J, et al. Household antimicrobial self-medication: a systematic review and meta-analysis of the burden, risk factors and outcomes in developing countries. BMC Public Health. 2015;15:742. https://doi.org/10.1186/s12889-015-2109-3

4. Hughes CM, McElnay JC, Fleming GF. Benefits and risks of self medication. Drug Saf. 2001;24(14):1027-37. https://doi. org/10.2165/00002018-200124140-00002

5. Chalker J. Improving antibiotic prescribing in Hai Phong Province, Viet Nam: the "antibiotic-dose" indicator. Bull World Health Organ. 2001;79(4):313-20.

6. Hong SH, Spadaro D, West D, Tak SH. Patient valuation of pharmacist services for self care with OTC medications. J Clin Pharm Ther. 2005;30(3):193-9. https://doi.org/10.1111/j.1365-2710.2005.00625.x

7. Singh I, Bard I, Jackson J. Robust resilience and substantial interest: a survey of pharmacological cognitive enhancement among university students in the UK and Ireland. PLoS One. 2014;9(19):e105969. https://doi.org/10.1371/journal.pone.0105969

8. Bassols A, Bosch F, Baños J-E. How does the general population treat their pain? A survey in Catalonia, Spain. J Pain Symptom Manage. 2002;23(4):318-28. https://doi.org/10.1016/s0885-3924(01)00415-8

9. Stosic R, Dunagan F, Palmer H, Fowler T, Adams I. Responsible self-medication: perceived risks and benefits of over-the-counter analgesic use. Int J Pharm Pract. 2011;19(4):236-45. https://doi.org/10.1111/j.2042-7174.2011.00097.X

10. Alghadeer S, Aljuaydi K, Babelghaith S, Alhammad A, Alarifi MN. Self-medication with antibiotics in Saudi Arabia. Saudi Pharm J. 2018;26(5):719-24. https://doi.org/10.1016/j.jsps.2018.02.018

11. Bennadi D. Self-medication: a current challenge. J Basic Clin Pharm. 2014;5(1):19-23. https://doi.org/10.4103/0976-0105.128253

12. Ramay BM, Lambour P, Cerón A. Comparing antibiotic self-medication in two socio-economic groups in Guatemala City: a descriptive cross-sectional study. BMC Pharmacol Toxicol. 2015;16:11. https://doi.org/10.1186/s40360-015-0011-3

13. Sherazi BA, Mahmood KT, Amin F, Zaka M, Riaz M, Javed A. Prevalence and measure of self-medication: a review. J Pharm Sci Res. 2012;4(3):1774-8.

14. Tenaw A, Tsige G. Self medication practice in Addis Ababa. Ethiop J Health Sci. 2004;14(1):1-13.

15. Brimstone R, Thistlethwaite JE, Quirk F. Behaviour of medical students in seeking mental and physical health care: exploration and comparison with psychology students. Med Educ. 2007;41(1):74-83. https://doi.org/10.1111/j.1365-2929.2006.02649.x

16. Hooper C, Meakin R, Jones M. Where students go when they are ill: how medical students access health care. Med Educ. 2005 ;39(6):588-93. https://doi.org/10.1111/j.1365-2929.2005.02175.x

17. Hoy D, Brooks P, Woolf A, Blyth F, March L, Bain C, et al. Assessing risk of bias in prevalence studies: modification of an existing tool and evidence of interrater agreement. J Clin Epidemiol. 2012;65(9):934-9. https://doi.org/10.1016/j.jclinepi.2011.11.014

18. Higgins JP, Thompson SG. Quantifying heterogeneity in a meta-analysis. Stat Med. 2002;21(11):1539-58.

19. Egger M, Davey Smith G, Schneider M, Minder C. Bias in meta-analysis detected by a simple, graphical test. BMJ. 1997;315(7109):629-34. https://doi.org/10.1136/bmj.315.7109.629

20. Liberati A, Altman DG, Tetzlaff J, Mulrow C, Gøtzsche PC, Ioannidis JP et al. The PRISMA statement for reporting systematic reviews and meta-analyses of studies that evaluate health care interventions: explanation and elaboration. Ann Intern Med. 2009;151(4):W65-94. https://doi.org/10.7326/0003-4819-151-4-200908180-00136

21. Lau GS, Lee KK, Luk CT. Self-medication among university students in Hong Kong. Asia Pac J Public Health. 1995;8(3):153-7. https://doi.org/10.1177/101053959500800301

22. Burak LJ, Damico A. College students' use of widely advertised medications. J Am Coll Health. 2000;49(3):118-21. https://doi. org/10.1080/07448480009596293

23. Cabrita J, Ferreira H, Iglésias P, Baptista T, Rocha E, Lopes Da Silva A et al. Patterns and determinants of psychoactive drug use in Lisbon University students: a population-based study. Pharm World Sci. 2004;26(2):79-82. https://doi.org/10.1023/ B:PHAR.0000018597.46246.34. 
24. Aguado MI, Nuñez MB, Dos Santos Antola L, Bregni C. Automedicación en Estudiantes de Farmacia de la Universidad Nacional del Nordeste, Argentina [Self-medication in students of pharmacy of the Northeast University, Argentina]. Acta Farma Bonaer. 2005;24(2):271-6.

25. McCabe SE, Teter CJ, Boyd C J. Illicit use of prescription pain medication among college students. Drug Alcohol Depend. 2005;77(1):37-47. https://doi.org/10.1016/j.drugalcdep.2004.07.005

26. James H, Handu SS, Al Khaja KAJ, Otoom S, Sequeira RP. Evaluation of the knowledge, attitude and practice of self-medication among first-year medical students. Med Princ Pract. 2006;15(4):270-5. https://doi.org/10.1159/000092989

27. Awad AI, Eltayeb IB. Self-medication practices with antibiotics and antimalarials among Sudanese undergraduate university students. Ann Pharmacother. 2007;41(7-8):1249-55. https://doi.org/10.1345/aph.1Ko68

28. Castronuovo C, Chiclana F, Giosso L, Pensa G, Prario M, Rebollo V, et al. Automedicación en Estudiantes de la Universidad Nacional de La Plata (Argentina) [A study regarding self-medication in students from the Universidad Nacional de La Plata (Argentina)]. Latin Am J Pharm. 2007;26(6):937-44.

29. Hussain A, Khanum A. Self-medication among university students of Islamabad, Pakistan: a preliminary study. Southern Med Review. 2008;1(1):14-6

30. Sawalha AF. A descriptive study of self-medication practices among Palestinian medical and nonmedical university students. Res Social Adm Pharm. 2008;4(2):164-72. https://doi.org/10.1016/j.sapharm.2007.04.004

31. Zafar SN, Syed R, Waqar S, Zubairi AJ, Vaqar T, Shaikh M, et al. Self-medication amongst university students of Karachi: Prevalence, knowledge and attitudes. J Pakistan Med Assoc. 2008;58(4):214-7.

32. Sawalha AF, Sweileh WM, Zyoud SH, Jabi SW. Self-therapy practices among university students in Palestine: focus on herbal remedies. Complement Ther Med. 2008 16(6):343-9. https://doi.org/10.1016/j.ctim.2007.12.002

33. Sarahroodi S, Arzi A. Self-medication with antibiotics, is it a problem among Iranian college students in Tehran? J Biol Sci. 2009;9(8):829-32. https://doi.org/10.3923/jbs.2009.829.832

34. Abay SM, Amelo W. Assessment of self-medication practices among medical, pharmacy, and health science students in Gondar University, Ethiopia. J Young Pharm. 2010;2(3):306-10. https://doi.org/10.4103/0975-1483.66798

35. de Aquino DS, de Barros JAC, da Silva MDP. A automedicacao e os academicos da area de saude [Self-medication and health academic staff]. Cien Saude Colet. 2010;15(5):2533-8. https://doi.org/10.1590/s1413-81232010000500027

36. Marin GH, Canas M, Carlson S, Silvestrini MP, Corva S, Mestorino N, et al. Self-medication, substance abuse and alcohol consumption in students attending to La Plata National University, Argentina. Latin Am J Pharm. 2010;29(8):1425-30.

37. Sapkota AR, Coker ME, Goldstein RER, Atkinson NL, Sweet SJ, Sopeju PO, et al. Self-medication with antibiotics for the treatment of menstrual symptoms in southwest Nigeria: a cross-sectional study. BMC Public Health. 2010;10. https://doi. org/10.1186/1471-2458-10-610

38. Sarahroodi S, Arzi A, Sawalha AF, Ashtarinezhad A. Antibiotics self-medication among southern Iranian university students. Int J Pharmacol. 2010;6(1):48-52. https://doi.org/10.3923/ijp.2010.48.52

39. Verma RK, Mohan L, Pandey M. Evaluation of self-medication among professional students in north India: proper statutory drug control must be implemented. Asian J Pharm Clin Res. 2010;3(1):60-4.

40. Chowdhury N, Yasmin H, Khandaker JN, Hossain F. An assessment of the health behaviors of dorm students in Bangladesh. Home Health Care Manag Pract. 2011;23(2):82-92. https://doi.org/10.1177/1084822310368634

41. El-Ezz NFA, Ez-Elarab HS. Knowledge, attitude and practice of medical students towards self-medication at Ain Shams University, Egypt. J Prev Med Hyg. 2011;52(4):196-200.

42. Gutema GB, Gadisa DA, Kidanemariam ZA, Berhe DF, Berhe AH, Hadera MG, et al. Self-medication practices among health sciences students: the case of Mekelle University. J Appl Pharm Sci. 2011;1(10):183-9.

43. Klemenc-Ketis Z, Hladnik Z, Kersnik J. A cross sectional study of sex differences in self-medication practices among university students in Slovenia. Coll Antropol. 2011;35(2):329-34.

44. Klemenc-Ketis Z, Kersnik J. The effect of demographic characteristics on self-medication patterns: a cross-sectional nationwide study from Slovenia. Coll Antropol. 2011;35(4):1237-42.

45. Mumtaz Y, Ashraf Jahangeer SM, Mujtaba T, Zafar S, Adnan S. Self-medication among university students of Karachi. J Liaquat Uni Med Health Sci. 2011;10(3):102-5

46. Souza LA F, da Silva CD, Ferraz GC, Sousa F, Pereira LV. The prevalence and characterization of self-medication for obtaining pain relief among undergraduate nursing students. Rev Lat Am Enfermagem. 2011;19(2):245-51. https://doi.org/10.1590/s010411692011000200004

47. Auta A, Banwat SB, Sariem CN, Shalkur D, Nasara B, Atuluku MO. Medicines in pharmacy students' residence and self-medication practices. J Young Pharm. 2012;4(2):119-23. https://doi.org/10.4103/0975-1483.96627

48. Banerjee I, Bhadury T. Self-medication practice among undergraduate medical students in a tertiary care medical college, West Bengal. J Postgrad Med. 2012;58(2):127-31. https://doi.org/10.4103/0022-3859.97175

49. da Silva MGC, Soares MCF, Muccillo-Baisch AL. Self-medication in university students from the city of Rio Grande, Brazil. BMC Public Health. 2012;12. https://doi.org/10.1186/1471-2458-12-339 
50. da Silva RCG, Oliveira TM, Casimiro TS, Vieira KAM, Tardivo MT, Faria Jr M, et al. Automedicação em acadêmicos Automedicação em acadêmicos do curso de medicina [Self-medication in academics from medical school. Medicina (Brazil)]. 2012;45(1):511 .

51. Donkor ES, Tetteh-Quarcoo PB, Nartey P, Agyeman IO. Self-medication practices with antibiotics among tertiary level students in Accra, Ghana: a cross-sectional study. Int J Environ Res Public Health. 2012;9(10):3519-29. https://doi.org/10.3390/ijerph9103519

52. Galato D, Madalena J, Pereira GB. Automedicacao em estudantes universitarios: a influencia da area de formacao [Self-medication among university students: the influence of the field of study]. Cien Saude Colet. 2012;17(12):3323-30. https://doi.org/10.1590/ S1413-81232012001200017

53. Ibrahim Sharif S, Mohamed Ibrahim OH, Mouslli L, Waisi R. Evaluation of self-medication among pharmacy students. Am J Pharmacol Toxicol. 2012;7(4):135-40.

54. Murtaza G, Nisar ur R, Khan SA, Noor T, Karim S, Bashir D, et al. Assessment of the knowledge, behavior and practice of self-medication amongst female students in a Pakistani university. Latin Am J Pharm. 2012;31(7):958-62.

55. Osemene KP, Lamikanra A. A study of the prevalence of self-medication practice among university students in southwestern Nigeria. Trop J Pharm Res. 2012;11(4):683-9. https://doi.org/10.4314/tjpr.v11i4.21

56. Pan H, Cui B, Zhang D, Farrar J, Law F, Ba-Thein W. Prior knowledge, older age, and higher allowance are risk factors for self-medication with antibiotics among university students in Southern China. PLoS ONE. 2012;7(7). https://doi.org/10.1371/journal.pone.0041314

57. Suaifan G, Shehadeh M, Darwish DA, Al-ljel H, Yousef AMM, Darwish RM. A cross-sectional study on knowledge, attitude and behavior related to antibiotic use and resistance among medical and non-medical university students in Jordan. Afr J Pharm Pharmacol. 2012;6(10):763-70. https://doi.org/10.5897/ajpp12.080

58. Tabiei S, Farajzadeh Z, Eizadpanah A. Self-medication with drug amongst university students of Birjand. Mod Care J. 2012;9(4):371-8.

59. Angamo MT, Wabe NT. Knowledge, attitude and practice of self-medication in southwest Ethiopia. Int J Pharm Sci Res. 2012;3(4):1005-10.

6o. Betancourt J, Ríos JL, Pagán I, Fabián C, González AM, Cruz SY, et al. Non-medical use of prescription drugs and its association with socio-demographic characteristics, dietary pattern, and perceived academic load and stress in college students in Puerto Rico. P R Health Sci J. 2013;32(2):89-94.

61. Imtiaz S, Malik N, Kamran. Conditions, frequencies, and sociodemographic factors leading self-medication practice in Sargodha area of Punjab Pakistan. J Appl Pharm. 2013;5(4):819-26.

62. Kumar N, Kanchan T, Unnikrishnan B, Rekha T, Mithra P, Kulkarni V, et al. Perceptions and practices of self-medication among medical students in coastal south India. PLoS One. 2013;8(8). https://doi.org/10.1371/journal.pone.0072247.

63. Purreza A, Khalafi A, Ghiasi A, Farrokh Mojahed F, Nurmohammadi M. [To identify self-medication practice among medical students of Tehran University of Medical Science]. Iran J Epidemiol. 2013;8(4):40-6. [In Farsi]

64. Ullah H, Khan SA, Ali S, Karim S, Baseer A, Chohan O, et al. Evaluation of self-medication amongst university students in Abbottabad, Pakistan; prevalence, attitude and causes. Acta Polon Pharmaceutica-Drug Res. 2013;70(5):919-22.

65. Al-Hussaini M, Mustafa S, Ali S. Self-medication among undergraduate medical students in Kuwait with reference to the role of the pharmacist. J Res Pharm Pract 2014;3:23-7. https://doi.org/10.4103/2279-042X.132706.

66. Brlić KČ, Holcer NJ, Sović S, Štimac D. Characteristics of self-medication for pain relief among first-year health care students in Zagreb, Croatia. Psychiatr Danub. 2014;26(Suppl. 3):459-65.

67. Damian L, Lupuşoru CE, Ghiciuc CM. Self-medication with antimicrobial drugs among university students in a Northeast region of Romania. Rev Med Chir Soc Med Nat Iasi. 2014;118(1):160-4.

68. Flaiti MA, Badi KA, Hakami WO, Khan SA. Evaluation of self-medication practices in acute diseases among university students in Oman. J Acute Dis. 2014;3(3):249-52. https://doi.org/10.1016/S2221-6189(14)60056-1

69. Ghafouri M, Yaghubi M, Lashkardoost H, Seyed Sharifi SH. [The prevalence of self-medication among students of Bojnurd universities and its related factors in 2013]. J North Khorasan Univ Med Sci. 2014;5(5):1129-35. [in Farsi]

70. Lukovic JA, Miletic V, Pekmezovic T, Trajkovic G, Ratkovic N, Aleksic D, et al. Self-medication practices and risk factors for self-medication among medical students in Belgrade, Serbia. PLoS One. 2014;9(12). https://doi.org/10.1371/journal.pone.0114644

71. Lv B, Zhou ZL, Xu GP, Yang DK, Wu LN, Shen Q, et al. Knowledge, attitudes and practices concerning self-medication with antibiotics among university students in western China. Trop Med Int Health. 2014;19(7):769-79. https://doi.org/10.1111/tmi.12322

72. Martinez JE, Pereira GAF, Ribeiro LGM, Nunes R, Ilias D, Navarro LGM. Study of self-medication for musculoskeletal pain among nursing and medicine students at Pontifícia Universidade Católica, São Paulo. Rev Bras Reumatol. 2014;54(2):90-4. https://doi.org/10.1016/j.rbre.2014.03.002

73. Pirzadeh A, Mostafavi F. Self-medication among students in Isfahan University of Medical Sciences based on health belief model. J Edu Health Promot. 2014;3:112. https://doi.org/10.4103/2277-9531.145904

74. Saeed MS, Alkhoshaiban AS, Al-Worafi YMA, Long CM. Perception of self-medication among university students in Saudi Arabia. Arch Pharm Pract. 2014;5(4):149-52. https://doi.org/10.4103/2045-080X.142049 
75. Shah SJ, Ahmad H, Rehan RB, Najeeb S, Mumtaz M, Jilani MH, et al. Self-medication with antibiotics among non-medical university students of Karachi: a cross-sectional study. BMC Pharmacol Toxicol. 2014;15. https://doi.org/10.1186/2050-6511-15-74

76. Sharif SI, Sharif RS. Self-medication among non-healthcare students of the University of Sharjah, United Arab Emirates. Arch Pharm Pract. 2014;5(1):35-41. https://doi.org/10.4103/2045-080X.128375

77. Patil SB, S H V, B V P, Santoshkumar J, Binjawadgi AS, Kanaki AR5. Self-medication practice and perceptions among undergraduate medical students: a cross-sectional study. J Clin Diagn Res. 2014 8(12):HC20-3. https://doi.org/10.7860/JCDR/2014/10579.5313

78. Alam N, Saffoon N, Uddin R. Self-medication among medical and pharmacy students in Bangladesh. BMC Res Notes. $2015 ; 8: 763$. https://doi.org/10.1186/s13104-015-1737-0.

79. Chiribagula VB, Mboni HM, Amuri SB, Kamulete GS, Byanga JK, Duez P, et al. Prevalence and characteristics of self-medication among students aged 18-35 residing in the Kasapa campus of the University of Lubumbashi. Pan Afr Med J. 2015;21:77. https:// doi.org/ 10.11604/pamj.2015.21.107.5651

8o. Ghaieth MF, Elhag SRM, Hussien ME, Konozy EHE. Antibiotics self-medication among medical and nonmedical students at two prominent Universities in Benghazi City, Libya. J Pharm Bioallied Sci. 2015;7(2):109-15. https://doi.org/ 10.4103/0975-7406.154432

81. Gholipour K, Tabrizi JS, Haghgoshayee E, Soltani R, Mousazadeh Y, Rasi V. [Investigating factors affecting self-medication and its pattern among students of Tabriz University of Medical Sciences, Iran, in 2012]. J Health Syst Res. 2015;11(4):736-40. [In Farsi]

82. Gunawardhana CB, Sakeena MHF, Sivayoganthan C. Awareness of rational medication use and antibiotic self-medication practices among undergraduate students in a university in Sri Lanka. Trop J Pharm Res. 2015;14(4):723-9. https://doi.org/10.4314/tjpr. v14i4.23

83. Ibrahim NK, Alamoudi BM, Baamer WO, Al-Raddadi RM. Self-medication with analgesics among medical students and interns in King Abdulaziz University, Jeddah, Saudi Arabia. Pakistan J Med Sci. 2015;31(1):14-8. https://doi.org/10.12669/pjms.311.6526.

84. Sharma A, Oommen S, Topno I, Saya RP. Perceptions and practices of self-medication in healthcare and non-healthcare university students in South India. J Basic Clin Physiol Pharmacol. 2015;26(6):633-40. https://doi.org/10.1515/jbcpp-2015-0025

85. Aashi MM, Alghanmi HA, Alhibshi RH, Alsaati BA, Aljohani NJ. Self-medication among medical student in King Abdul-Aziz University. Int J Res Med Sci. 2016;4(3):942-6. http://dx.doi.org/10.18203/2320-6012.ijrms20160547

86. Ahmadi SM, Jamshidi K, Sadeghi K, Abdi A, Vahid MP. The prevalence and affecting factors on self-medication among students of Kermanshah University of Medical Science in 2014. J Clin Diagn Res. 2016;10(5):ICo1-IC4. https://doi.org/10.7860/ JCDR/2016/18018.7847

87. Albasheer OB, Mahfouz MS, Masmali BM, Ageeli RA, Majrashi AM, Hakami AN, et al. Self-medication practice among undergraduate medical students of a Saudi tertiary institution. Trop J Pharm Res. 2016;15(10):2253-9. https://doi.org/10.4314/tjpr. v15i10.26

88. Ali AS, Ahmed J, Sonekhi GB, Fayyaz N, Zainulabdin Z, Jindani R. Practices of self-medication with antibiotics among nursing students of Institute of Nursing, Dow University of Health Sciences, Karachi, Pakistan. J Pakistan Med Assoc. 2016;66(2):235-7.

89. Alkhatatbeh MJ, Alefan Q, Alqudah MAY. High prevalence of self-medication practices among medical and pharmacy students: a study from Jordan. Int J Clin Pharmacol Ther. 2016;54(5):390-8. https://doi.org/10.5414/cp202451

90. Banerjee I, Sathian B, Gupta RK, Amarendra A, Roy B, Bakthavatchalam P, et al. Self-medication practice among preclinical university students in a medical school from the city of Pokhara, Nepal. Nepal J Epidemiol. 2016;6(2):574-81. https://doi.org/10.3126/ nje.v6i2.15165

91. Birru EM, Abay Z, Abdelwuhab M, Basazn A, Sirak B, Teni FS. Management of headache and associated factors among undergraduate medicine and health science students of University of Gondar, North West Ethiopia. J Headache Pain. 2016;17. https:// doi.org/10.1186/s10194-016-0647-4

92. Ibrahim UI, Lua PL. Self-medication practices among undergraduates of a public university. Malaysian J Public Health Med. 2016;16(3):23-8

93. Iuras A, Franco Marques AA, Da Fonseca Roberti Garcia L, Santiago MB, Lima Santana LK. Prevalência da automedicação entre estudantes da Universidade do Estado do Amazonas (Brasil) [Prevalence of self-medication among students of State University of Amazonas (Brazil)]. Rev Port Estomatol Cir Maxilofac. 2016;57(2):104-11. https://doi.org/10.1016/j.rpemd.2016.01.001

94. Jamshed SQ, Wong PS, Yi HC, Yun GS, Khan MU, Ahmad A. Self-medication practices among female students of higher educational institutions in Selangor, Malaysia: A quantitative insight. J Pharm Bioallied Sci. 2016;8(3):217-22. https://doi. org/10.4103/0975-7406.172662

95. Jiménez-Núñez FG, Ruiz-Palmero J, López-Cózar Ruiz L, Gómez-García M. Impact of a training action on the prevalence of self-medication among students from the Faculty of Education Sciences at the University of Malaga. Educ Med. 2016;17(4):18692. https://doi.org/10.1016/j.edumed.2016.03.004

96. Johnson D, Sekhar HS, Alex T, Kumaraswamy M, Chopra RS. Self-medication practice among medical, pharmacy and nursing students Int J Pharm Pharm Sci. 2016;8(7):443-7.

97. Juibari TA, Mirzaei-Alavijeh M, Jalilian F, Karami-Matin B, Mahboubi M, Aghaei A. Prevalence and socio-cognitive determinants of self-medication among college students. Int J Adv Biotechnol Res. 2016;7(4):1540-5

98. Kumar R, Goyal A, Padhy BM, Gupta YK. Self-medication practice and factors influencing it among medical and paramedical students in India: A two-period comparative cross-sectional study. J Nat Sci Biol Med. 2016;7(2):143-8. https://doi. 
org/10.4103/0976-9668.184700.

99. Morowatisharifabad MA, Keshavarzi A, Sohrevardi SM, Askairshahi M, Mehrjerdi AV, Jouybari TA, et al. Cognitive factors related in self-medication among college students based on prototype/willingness model. Int J Trop Med. 2016;11(5):143-8. https://doi. org/10.3923/ijtmed.2016.143.148

100. Noor T, Sajjad A, Asma A. Frequency, character and predisposing factor of headache among students of medical college of Karachi. J Pakistan Med Assoc. 2016;66(2):159-64.

101. Saleem Z, Saeed H, Ahmad M, Yousaf M, Hassan HB, Javed A, et al. Antibiotic self-prescribing trends, experiences and attitudes in upper respiratory tract infection among pharmacy and non-pharmacy students: a study from Lahore. PLoS ONE. 2016;11(2). https://doi.org/10.1371/journal.pone.0149929

102. Williams A, Crawford K. Self-medication practices among undergraduate nursing and midwifery students in Australia: a cross-sectional study. Contemp Nurse. 2016;52(4):410-20. https://doi.org/10.1080/10376178.2016.1197782

103. Yadav AK, Rai BK, Budhathoki SS, Ghimire A, Shrestha SR, Malla GB. Self-prescription of paracetamol by undergraduate students in BP Koirala Institution of Health Sciences. J Nepal Med Assoc. 2016;55(1):11-5.

104. Zhu X, Pan H, Yang Z, Cui B, Zhang D, Ba-Thein W. Self-medication practices with antibiotics among Chinese university students. Public Health. 2016;130:78-83. https://doi.org/10.1016/j.puhe.2015.04.005

105. Al-Ameri RJ, Abd Al-Badri HJ, Lafta RK. Prevalence of self-medication among university students in Baghdad: a cross-sectional study from Iraq. East Mediterr Health J. 2017;23(2):87-93.

106. Gelayee DA. Self-medication pattern among social science university students in northwest Ethiopia. J Pharm. 2017. https://doi. org/10.1155/2017/8680714

107. Haroun MF, Al-Kayali RS. Self-medication among undergraduate medical students in two universities in Syria. Int J Pharm Sci Res. 2017;8(4):1881-6. https://doi.org/10.13040/IJPSR.0975-8232.8(4).1881-86

108. Helal RM, Abou-ElWafa HS. Self-medication in university students from the city of Mansoura, Egypt. J Environ Public Health. 2017;2017. https://doi.org/10.1155/2017/9145193

109. Jakaria M, Hasant A, Tarek MI, Islam MZ, Zaman R, Parvez M, et al. Evaluation of self-medication among students from different universities in Chittagong, Bangladesh. J Med Bangladesh. 2017;18(1):15-20. https://doi.org/10.3329/jom.v18i1.31171

110. Shehnaz SI, Agarwal AK, Khan N. A systematic review of self-medication practices among adolescents. J Adolesc Health. 2014;55(4):467-83. https://doi.org/10.1016/j.jadohealth.2014.07.001

111. Domingues PHF, Galvão TF, de Andrade KRC, de Sá PTT, Silva MT, Pereira MG. Prevalence of self-medication in the adult population of Brazil: a systematic review. Rev Saude Publica. 2015;49:36. https://doi.org/10.1590/so034-8910.2015049005709

112. Saradamma RD, Higginbotham N, Nichter M. Social factors influencing the acquisition of antibiotics without prescription in Kerala State, south India. Soc Sci Med. 2000;50(6):891-903. https://doi.org/10.1016/s0277-9536(99)00380-9

113. Klemenc-Ketis Z, Hladnik Z, Kersnik J. Self-medication among healthcare and non-healthcare students at University of Ljubljana, Slovenia. Med Princ Pract. 2010;19(5):395-401. https://doi.org/10.1159/000316380

114. Hernandez-Juyol M, Job-Quesada JR. Dentistry and self-medication: a current challenge. Med Oral. 2002;7(5):34-7.

115. Balbuena FR, Aranda AB, Figueras A. Self-medication in older urban Mexicans: an observational, descriptive, cross-sectional study. Drugs Aging. 2009;26(1):51-60. https://doi.org/10.2165/0002512-200926010-00004

116. Kauffman SE, Silver P, Poulin J. Gender differences in attitudes toward alcohol, tobacco, and other drugs. Soc Work. 1997 42(3):231-41.

117. Sapkota AR, Coker ME, Rosenberg Goldstein RE, Atkinson NL, Sweet SJ, Sopeju PO, et al. Self-medication with antibiotics for the treatment of menstrual symptoms in southwest Nigeria: a cross-sectional study. BMC Public Health. 2010;10:610. https://doi. org/10.1186/1471-2458-10-610.

118. Habeeb GF, Gearhart JG. Common patient symptoms: patterns of self-treatment and prevention. J Miss State Med Assoc 1993;34(6):179-81.

119. Shankar PR, Partha P, Shenoy N. Self-medication and non-doctor prescription practices in Pokhara valley, western Nepal: a questionnaire-based study. BMC Fam Pract. 2002;3:17. https://doi.org/10.1186/1471-2296-3-17

120. Azami-Aghdash S, Mohseni M, Etemadi M, Royani S, Moosavi A, Nakhaee M. Prevalence and cause of self-medication in Iran: a systematic review and meta-analysis article. Iran J Public Health. 2015;44(12):1580-93. 